\title{
The Role of Physical Therapy in the Re-education of Prehension in Elderly Patients
}

\author{
Cristuță Alina-Mihaela ${ }^{1 *}$ \\ ${ }_{1}^{1}$ Vasile Alecsandri" University of Bacău, Calea Mărășești 157, 600115, Romania
}

Keywords: physical therapy, evaluation, prehension, elder.

\begin{abstract}
The recovery assistance in geriatrics targets two categories of patients - the elderly who become deficient and the deficients who become elders. Both categories achieve a particularly high percentage, due to most of the chronic illnesses that are so frequent with the elderly install dysfunctions that strengthen in time, and the deficients, due to the care they receive, reach the third age in an increasing number. The scope of the research was to highlight the role of physical therapy in the prehension re-education of the third age individuals, and the goals regarded the evaluation of the functional capacity; the detection of the functional dependency extent; prehension re-education with this category of age. The research methods used were set-up based on the research goals, and, therefore, the method of the bibliographical study method, the tests method, the statistical mathematical method and the graphical method were used.
\end{abstract}

\section{Introduction}

Aging is a natural process, characterized by the occurrence of certain physical, physiological and intellectual characteristics due to the involution of all body apparatus and systems. The pathology of aged ages is specific through its pluralism. The high proportion of elderly developing functional deficits is explained by the multiple chronic diseases that they have.

Therefore, the individuals over 65 have $2 x$ more functional deficits than the individuals under 65 , they have $4 \mathrm{x}$ more limited activity, they see the physician $42 \%$ more frequently, they are hospitalized $2 x$ more frequently and stay in hospital for a period longer by $50 \%$ (Ciucurel \& Iconaru, 2008).

In the context of aging, that we may resume to a progressive descent of the functional capacity, at a critical point of time (that of autonomy loss), the physical activity must be seen as a first degree ameliorative factor and as a public health preventive and corrective action.

\footnotetext{
*E-mail: a.cristuta@yahoo.com;
} 


\section{Material and methods}

The research was performed between December 2014 - June 2015, within „Club 60+” Bacău and it was staged as it follows: stage I (December, 2014), matched the period in which I have selected the experimental group of subjects and the research location, and it also included the initial test of the selected group Functional hand index, Michigan quiz, Global motor balance and Prehension evaluation; stage II (January - May, 2015), included the actual research performance, that consisted of the implementation of all actions meant to attain the set-up goal; the stage III (June, 2015), represented the final research phase, when I conducted the final test and I have collected, recorded, processed and interpreted the results obtained on the experimental group of subjects.

The purpose of the research was to highlight the significance of physical therapy in the prehension re-education with the third aged individuals, and the goals regarded the evaluation of the functional capacity, the detection of the functional dependency level, and the prehension re-education at this category of age.

This research started from the hypotheses stating that by applying specific tests one can determine the dependence level of the subjects and after establishing the functional level, and through the intervention programs, the functional ability of the hand will improve, and implicitly the quality of life will be better.

The research methods used were set-up based on the research goals, and, therefore, the bibliographical study method, the tests method, the data record and processing method and the graphical method were used (Epuran, 2005).

In view of evaluation of the functional capacity and detection of the functional dependency level, the subjects were bilaterally evaluated through:

- Functional index - hand, that consists of a series of manual actions performed by the patient, and that may be interpreted as 0 - no-difficulty possibility, 1 - average difficulty possibility, 2 - important difficulty possibility, 3 impossibility, (Vaillant, 1999);

- Michigan quiz, refers to the hands' functionality in the past week, with the ranking system: 1 - very good, 2 - good, 3 - satisfactory, 4 - difficult, 5 - very difficult, as well as to the hands' ability to accomplish various tasks in the past week, with the ranking system: 1 - never difficult, 2 - little difficult, 3 - anything difficult, 4 - moderate difficulty, 5 - very difficult, (Balint, 2007);

- global motor balance, regarding the actions of the upper limb, with the interpretation: 0 - absence of movement; 1 - weak movement that only interests the intention; 2 - only partial movement; 3 - complete amplitude difficult movement; 4 - easy movement, although with execution speed and force lower than the healthy side; 5 - normal movement, (Manole \& Manole, 2009);

- prehension evaluation, through evaluation of the six types of prehension, with the following ranking: 0 - absence of movement; 1 - weak movement that only interests the intention; 2 - only partial movement; 3 - complete amplitude difficult movement; 4 - easy movement, although with execution speed and force lower than the healthy side; 5 - normal movement, (Cordun, 1999; Moraru \& 
Pâncota, 1999).

I would like to specify that the tests applied for the functional hand capacity, guided the applicative intervention, meant to increase the independence level of subject.

Methodology of the physical therapy intervention

The following aspects shall be considered in the process of regaining the hand movement ability:

$>$ the exercises should be structured based on individual peculiarities and patient's age;

$>$ the patient should become aware of the means to regain the functionality of his hand;

$>$ the patient should focus on the most correct movement execution, knowing that failure and refusal are excluded;

$>$ it should carefully follow the progressivity related to the three basic factors: easiness, accuracy and velocity, to which it should associate other elements such as gesture rhythmicity and movements amplitude, that should serve the purpose;

$>$ it should rebuild the movements' engrams by repenting the exercises until it reaches a functional movements' execution, ensuring a fair ratio between gesture repeat and appropriate pauses;

$>$ it is recommended that, while exercising, the patient verbalizes each movement, and, in the end, the patient should express its view about the aspects it considers positive, as well as about those it considers negative. This way, the patient is able to have better awareness of each and every action and it avoids the monotony during the recovery process;

$>$ following detailed evaluation of the functional deficit, the usual gestures are corrected in such manner that these stop worsening the deficit and, at the same time, that such gestures provide the patient with the maximum functional independency allowed by the deformity seriousness.

The physiological and emotional reaction of the individual subjects, their psychic mood and motility qualities were taken into account during the performance of the recovery program.

\section{Results and Discussions}

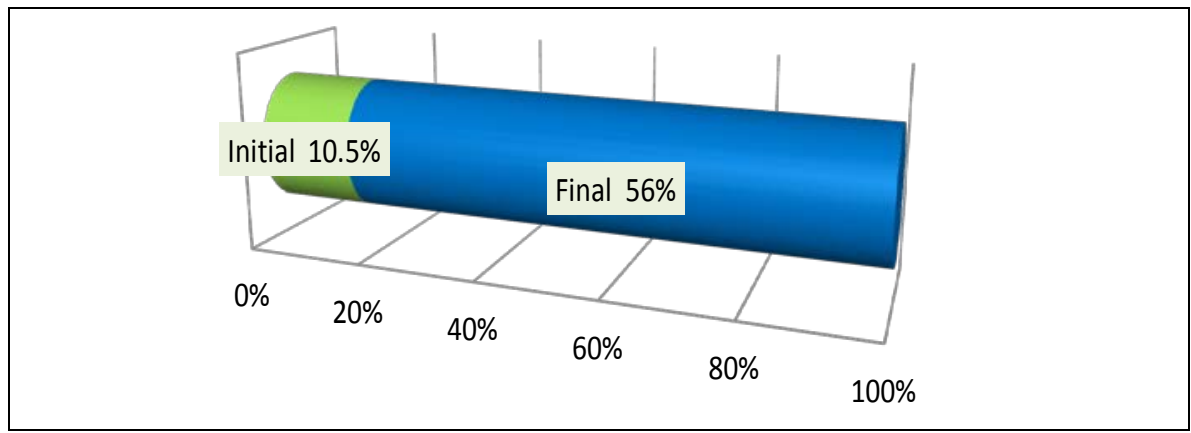

Figure 1. Functional index - hand 
Figure 1 includes the percentage values of the subject S.N.; hence, initially, a percentage of $10.5 \%$ out of $35 \%$ is allocated to the index actions "possible with important difficulty $2 "$, and finally, a percentage of $56 \%$.

In case of the functional index - hand, at the initial evaluation a percentage of $10.5 \%$ from max. 35\% was obtained for the index "possible with important difficulty 2", and, at the final evaluation, a percentage of $45.5 \%$ from max. $65 \%$ was obtained for the index "possible with average difficulty 1 " and $10.5 \%$ out of $35 \%$ for the index "possible with important difficulty 2". Following the analysis of such data, it is found that there is a difference of percentage progressivity of $45.5 \%$.

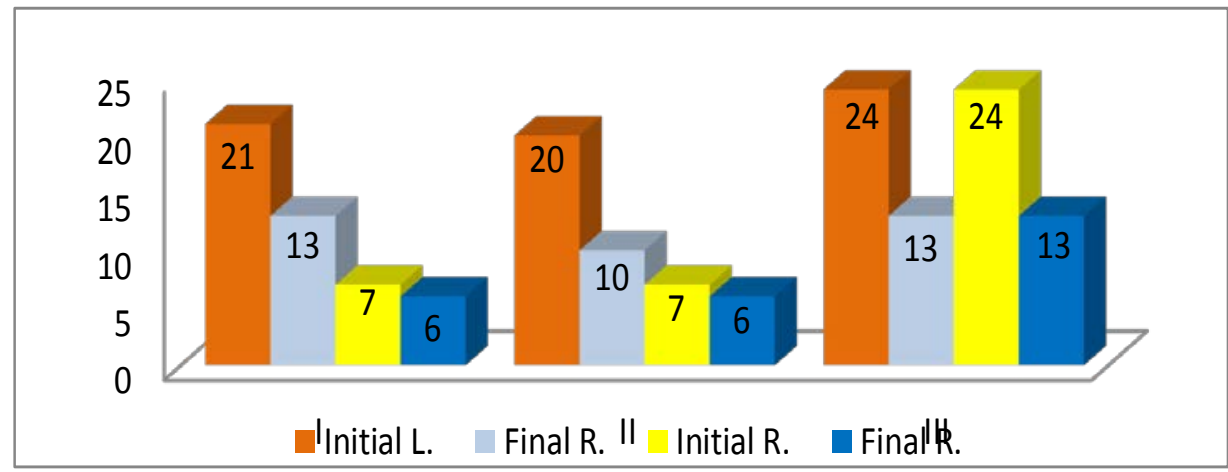

Figure 2. Comparative Michigan quiz

Figure 2 contains the comparative initial and final values obtained for the item Michigan quiz, regarding the "hands functionality in the past week, manual abilities to fulfil various tasks during the past week, as well as actions meant for simultaneous hands functionality".

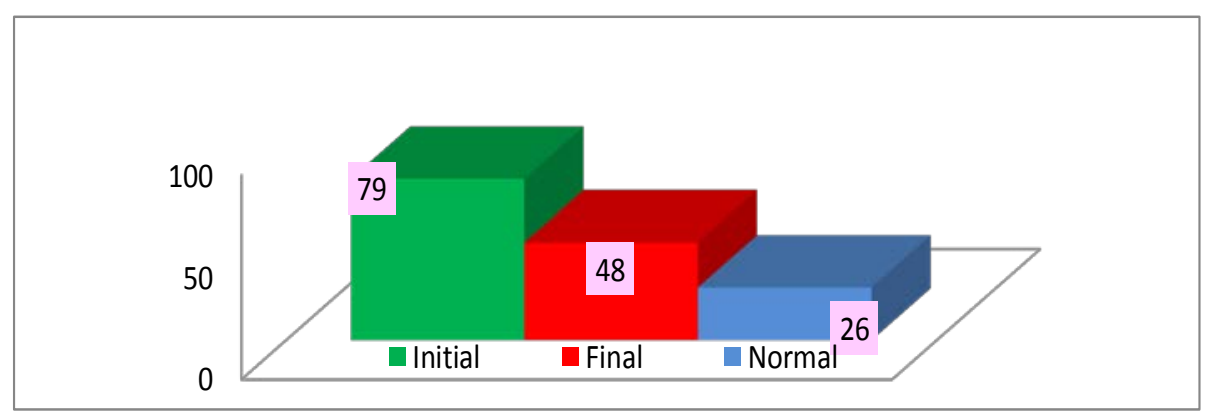

Figure 3. Michigan quiz

Figure 3 shows the positive evolution of the initial and final values obtained, against the normal value of the Michigan quiz.

After implementing the Michigan quiz, for the level I regarding the items "hands' functionality in the past week", at the initial evaluation of the upper left limb, a score of 21 points was obtained, with a difference of 16 points against the 
normal (5 points), and for the upper right limb a score of 7 out of 5 points was obtained, with a difference of 2 points. After the final evaluation, at the level of the upper left limb 13 points out of 5 were obtained, with a difference of 8 points, and, at the level of the upper right limb, 6 points out of 5 were obtained.

For the level II regarding the items related to "hands' ability to fulfil various tasks during the past week", the upper left limb obtained 20 points out of 5 normal at the initial evaluation, and 10 points out of 5 at the final evaluation, with a descendent progressivity of 10 points. The upper right limb initially obtained 7 points, and, finally, 6 points out of 5 normal.

At the level III, regarding the "actions with both hands", at the initial evaluation 24/6 points were obtained, and, at the final evaluation, 13/6 points, with a progressivity of 11 points. After presenting the values obtained with details about each level within the quiz, the conclusion is that, at global level, in this case, a total of 79/16 points were initially obtained and 48/16 points in the end, with a difference of 31 points.

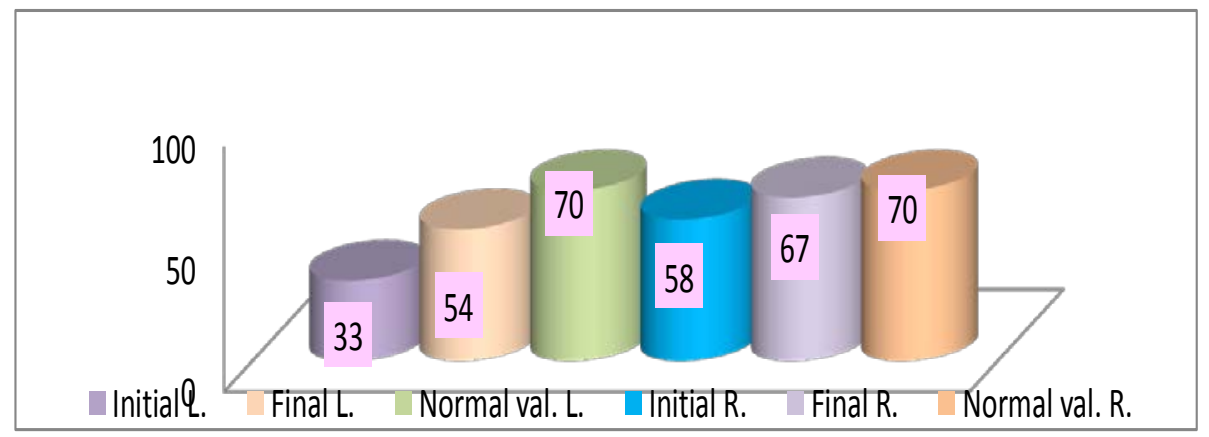

Figure 4. Evolution of the Global motor balance

Figure 4 shows the rising trend of the values obtained following the initial and final tests of the normal hand movements, in various activities within the Global Motor Balance.

The global motor balance records a progressivity of 21 points for the upper left limb, initially obtaining 33 points and finally 54 points/70, and 9 points for the upper right limb, and, therefore, 58/70 points were obtained initially and $67 / 70$ points were obtained in the end. 


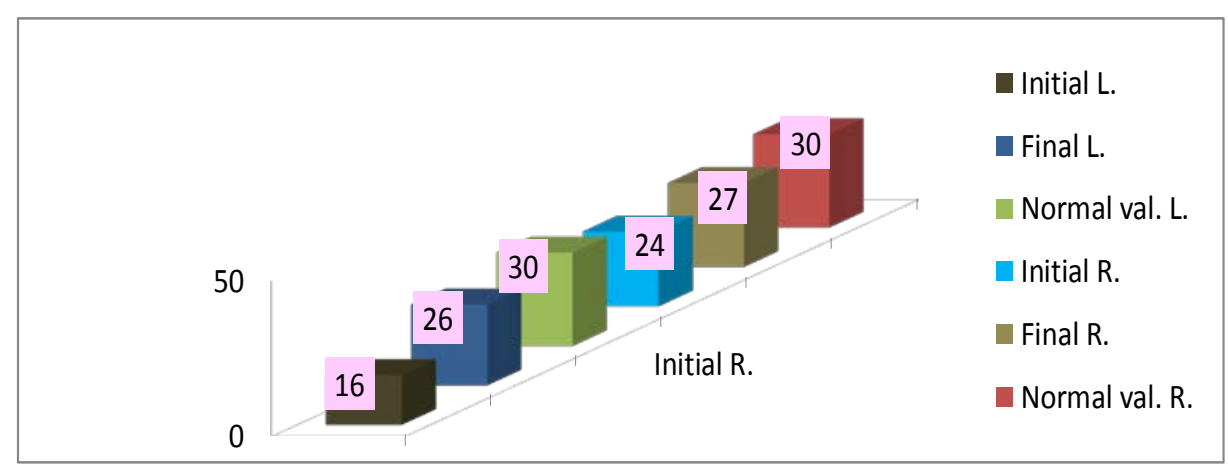

Figure 5. Prehension

Figure 5 shows the positive trend of the initial and final values obtained, against the normal prehension value.

In case of the Prehension type, it is shown the progressivity obtained, and, therefore, initially, a number of 16 points were obtained for the left hand and, finally, a number of 26 points out of 30 points normal in total, the movements being performed partially or on the entire amplitude, but with difficulty. On the right hand, a number of 24 points were initially obtained, and, in the end, a number of 27 points, out of total 30 points.

\section{Discussions}

This research tried to emphasize the importance of physical therapy in reeducating prehension in elderly people, through the assessment of the functional capacity, determination of the dependence level and reeducation of prehension in this age category.

The scientific paper "Painful hand in elderly patients" (Nica, Mologhianu, Nartea, Constantinovici, 2015, p. 342) presents the multiple physio-pathological and clinical aspects of the aging found in the hand. Combined with the pain, they can determine on various levels the dysfunctional aspects that go from functional impotence to disability. The paper reviews the most frequent situations regarding the painful hand in elderly patients, mostly in a rheumatic and posttraumatic context.

In order to analyze the painful hand in an elderly patient and decide and select personalized therapy and rehabilitation programs, one must review the clinical-functional aspects and consider the various pathological and physiological issues of the elderly patient, in order to set realistic and not "top performance" goals.

\section{Conclusions}

Over the course of the research, the objectives for each stage and the verification of the hypotheses were considered. Thus, some conclusive, possibly generalizing elements can be established, in regards to the importance of physical therapy in re-educating prehension in elderly people. 
Both hypotheses are verified, the applied tests revealing both the degree of independence and functional ability - initially, and the progress after the rehabilitation program, thus, "after establishing the functional level and through the specific intervention programs, the functional ability of the hand will improve, and implicitly the quality of life."

After comparing the results of the two examinations, initial and final, one can see an obvious improvement of the prehension in the patients who were involved in this research. It was noticed that the rehabilitation level of the subjects does not depend only on the quality and quantity of the work done by the physical therapist, but also on other factors, of which: the seriousness of the nervous lesion, this referring to both its length and location; the physical potential of the patient at the moment of contracting the illness; it is very important how soon can the rehabilitation treatment can be implemented. The sooner the rehabilitation starts, the better the results. This way there will be no more complications, such as muscular-tendinous retractions, or bad postures. Also, the risk of pressure ulcers and pulmonary complications is lowered; the degree of participation of the patient in his own treatment.

The patient's participation in the rehabilitation program must be done rigorously, with a frequency that is right for the physical potential of the patient and must have continuity. If, for various reasons, the patients cannot participate in their rehabilitation program, its dynamics is negatively influenced, leading to a diminished rehabilitation rhythm. In some cases, it can lead even to a regression of the motor function, explicable by the nervous function not being stimulated.

\section{References}

1. BALINT, T. (2007). Evaluarea aparatului locomotor, Iași: Pim;

2. CIUCUREL C., \& ICONARU E. (2008). Introducere în Gerontologie, Craiova: Universitaria;

3. CORDUN, M. (1999). Kinetologie medicală, București: Axa;

4. EPURAN, M. (2005). Metodologia cercetării activităților corporale, București: FEST;

5. MANOLE, V., \& MANOLE, L. (2009). Evaluare motrică și funcțională în kinetoterapie, Iași: Pim;

6. MORARU, GH., \& PÂNCOTA, V. (1999). Recuperarea kinetică în reumatologie, Timișoara: Imprimeriei de Vest, 33;

7. NICA, A.S., MOLOGHIANU, G., NARTEA, R., \& CONSTANTINOVICI, M.I. (2015). Practica medicalå, 10, 4(42): 342;

8. VAILLANT, J. (1999). Arthrose de la main: Evaluer les limitations fonctionnelles, Kinésitherapie Scientifique, 393: 63-64. 


\title{
Rolul Kinetoterapiei în Reeducarea Prehensiunii la Persoanele Vârstnice
}

\author{
Cristuță Alina-Mihaela ${ }^{1}$ \\ 'Universitatea „Vasile Alecsandri” din Bacău, Calea Mărășești 157, 600115, România
}

Cuvinte cheie: kinetoterapie, evaluare, prehensiune, vârstnic

\section{Rezumat}

Asistența de recuperare în geriatrie se adresează la două categorii de pacienți - bătrânilor care devin deficienți și deficienților care devin bătrâni. Ambele categorii realizează procente deosebit de ridicate, căci majoritatea bolilor cronice atât de frecvente la vârstnici instalează disfuncții care se accentuează în timp, iar deficienții, prin îngrijirile primite, ajung la vârsta a III-a într-un număr din ce în ce mai mare. Scopul cercetării a fost de a evidenția rolul kinetoterapiei în reeducarea prehensiunii la persoanele de vârsta a III-a, iar obiectivele au vizat evaluarea capacității funcționale; depistarea gradului de dependență funcțională; reeducarea prehensiunii la această categorie de vârstă. Metodele de cercetare folosite au fost stabilite în funcţie de obiectivele cercetării, astfel s-a folosit metoda studiului bibliografic, metoda testelor, metoda statistico-matematică şi metoda grafică.

\section{Introducere}

Îmbătrânirea este un proces natural, care se caracterizează prin apariția anumitor caracteristici fizice, fiziologice și intelectuale, datorită involuției tuturor aparatelor și sistemelor organismului. Patologia vârstelor înaintate este specifică prin pluralismul său. Proporția mare a persoanelor vârstnice care dezvoltă deficite funcționale se explică prin multiplele boli cronice prezente la aceștia.

Astfel, persoanele peste 65 ani prezintă de 2 ori mai multe deficite funcționale, comparativ cu cele sub 65 ani, au de 4 ori mai limitată activitatea, consultă medicul cu 42\% mai des, se internează de 2 ori mai frecvent și rămân în spital o perioadă cu 50\% mai lungă (Ciucurel \& Iconaru, 2008).

În contextul îmbătrânirii, pe care o putem rezuma ca pe un declin progresiv al capacităţii funcţionale, la un moment critic (cel al pierderii autonomiei), activitatea fizică trebuie percepută ca un factor atenuant de prim rang şi ca o măsură de sănătate publică, preventivă şi corectivă.

\section{Material şi metode}

Cercetarea s-a desfășurat în perioada decembrie 2014 - iunie 2015, în cadrul „Club 60+" Bacău și a fost etapizată astfel: etapa I-a (decembrie 2014), a corespuns perioadei în care mi-am ales eşantionul de subiecţi şi locul de desfăşurare al cercetării, şi a cuprins şi testarea iniţială a grupului ales - Indice funcțional mâna, Chestionarul Michigan, Bilanț motor global și Evaluarea prehensiunii; etapa a-II-a (ianuarie-mai 2015), s-a identificat cu desfăşurarea propriu-zisă a cercetării, care a constat în aplicarea tuturor măsurilor de intervenție 
în vederea atingerii scopului propus; etapa a-III-a (iunie 2015), a reprezentat faza finală cercetării în care am efectuat testarea finală şi am colectat, înregistrat, prelucrat şi interpretat rezultatele obţinute pe eşantionul de subiecți.

Scopul cercetării a fost de a evidenția importanța kinetoterapiei în reeducarea prehensiunii la persoanele de vârsta a III-a, iar obiectivele au vizat evaluarea capacității funcționale; depistarea gradului de dependență funcțională; reeducarea prehensiunii la această categorie de vârstă.

În cercetare, s-a plecat de la ipotezele precum că prin aplicarea testelor specifice, depistăm gradul de dependență a subiecților și că în urma stabilirii nivelului funcțional și prin programele de intervenție specifice, se va îmbunătății capacitatea funcțională a mâinii și implicit creșterea calității vieții.

Metodele de cercetare folosite au fost stabilite în funcţie de obiectivele cercetării, astfel s-a folosit metoda studiului bibliografic, metoda testelor, metoda înregistrării și prelucrării datelor şi metoda grafică (Epuran, 2005

În vederea evaluării capacității funcţionale și a depistării gradului de dependență funcțională, s-a realizat evaluarea subiecților bilateral prin:

- Indicele funcțional - mână, ce constă într-o serie de acțiuni manuale realizate de pacient, ce prezintă interpretare de posibilitate fără dificultate 0 , posibilitate cu dificultate medie 1 , posibilitate cu dificultate importantă 2, imposibiltate 3, (Vaillant, 1999);

- Chestionarul Michigan, se referă la funcționalitatea mâinilor în decursul ultimei săptămâni, cu sistemul de notare: 1 - foarte bine, 2 - bine, 3 - satisfăcător, 4 - greu, 5 - foarte greu, cât și la abilitatea mâinilor pentru a îndeplini diverse sarcini pe parcursul ultimei săptămâni, cu sistemul de notare: 1 - deloc dificil, 2 puțin dificil, 3 - cât de cât dificil, 4 - dificultate moderată, 5 - foarte dificil, (Balint, 2007);

- Bilanțul motor global, ce vizează acțiunile membrului superior, cu interpretarea: 0 - absența mișcării; 1 - mișcare slabă ce interesează numai intenția; 2 - mișcare se realizează numai parțial; 3 - mișcarea se realizează pe toată amplitudinea, cu dificultate; 4 - mișcarea se realizează cu ușurință, dar cu forță și viteză de execuție mai scăzute decât partea sănătoasă; 5 - mișcarea normală, (Manole \& Manole, 2009);

- Evaluarea prehensiunii, prin evaluarea celor șase tipuri de prehensiune, cu următoarea cotație: 0 - absența mișcării; 1 - mișcare slabă ce interesează numai intenția; 2 - mișcare se realizează numai parțial; 3 - mișcarea se realizează pe toată amplitudinea, cu dificultate; 4 - mișcarea se realizează cu ușurință, dar cu forță și viteză de execuție mai scăzute decât partea sănătoasă; 5 - mișcarea normală, (Moraru \& Pâncota, 1999).

Precizez că aceste teste aplicate privind capacitatea funcțională a mâinii, au orientat intervenția aplicativă, în scopul creșterii gradului de independență.

\section{Metodologia interventiei kinetoterapeutice}

În procesul de redobândire a capacității de mișcare a mâinii, se vor avea în vedere următoarele aspecte: 
exercițiile să fie structurate în funcție de particularităţile individuale și vârsta pacientului; mâinii sale;

> pacientul să conșientizeze mijloacele de redobândire a funcționalității

$>$ să-și concentreze atenția asupra execuției cât mai corecte a mișcării, cunoscând că eșecul și refuzul sunt excluse;

să urmărească cu atenție progresivitatea în legătură cu cei trei factori de bază: ușurința, precizia și rapiditatea, la care să asocieze și alte elemente cum ar fi ritmicitatea gestului și amplitudinea mișcărilor, care trebuie să fie în accord cu scopul urmărit;

să-și refacă engramele mișcărilor prin repetarea exercițiilor, până se ajunge la o execuție funcțională a mișcărilor, asigurându-se un raport corect între repetarea gestului și pauzele corespunzătoare;

$>$ se recomandă ca în timpul efectuării exercițiilor, pacientul să verbalizeze fiecare mișcare, iar la sfârșit să-și prezinte opinia asupra aspectelor pe care le consideră pozitive, dar și asupra celor negative. În acest mod, pacientul poate conștientiza mai bine fiecare acțiune și se evită monotonia din timpul procesului de recuperare;

$>$ după o evaluare detaliată a defícitului funcţional, se corectează gesturile uzuale în aşa manieră încât acestea să nu mai contribuie la agravarea deficitului şi în acelaşi timp să ofere bolnavului maximum de independenţă funcţională permisă de gravitatea deformaţiilor.

În desfăşurarea programului de recuperare s-a avut în vedere în permanenţă reacţia fiziologică şi emoţională a fiecărui subiect, dispoziţia lui psihică şi calităţile motrice ale acestuia.

\section{Rezultate şi discuţii}

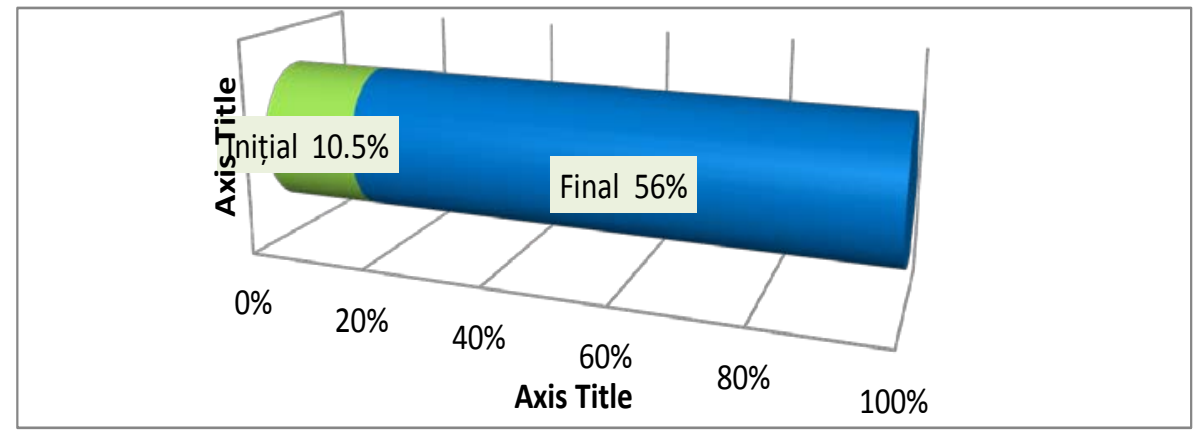

Figura 1. Reprezentarea grafică a Indicelui funcțional - mână

În reprezentarea grafică nr. 1, sunt prezentate valorile procentuale ale subiectului S.N., astfel, iniţial s-a determinat un procent de 10.5\% din 35\% alocat acțiunilor indicatorului "posibil cu dificultate importantă 2", și final, un procent de $56 \%$. 
În cazul Indicelui funcțional - mână, la evaluarea inițială s-a obținut un procent de $10.5 \%$ din maximum de $35 \%$ pentru indicatorul "posibil cu dificultate importantă 2", iar la evaluarea finală s-a obținut un procent de $45.5 \%$ din maximum de $65 \%$ pentru indicatorul "posibil cu dificultate medie 1" și $10.5 \%$ din $35 \%$ pentru indicatorul "posibil cu dificultate importantă 2". În urma analizei acestor date, se constată că există o diferență de progresivitate procentuală de $45.5 \%$.

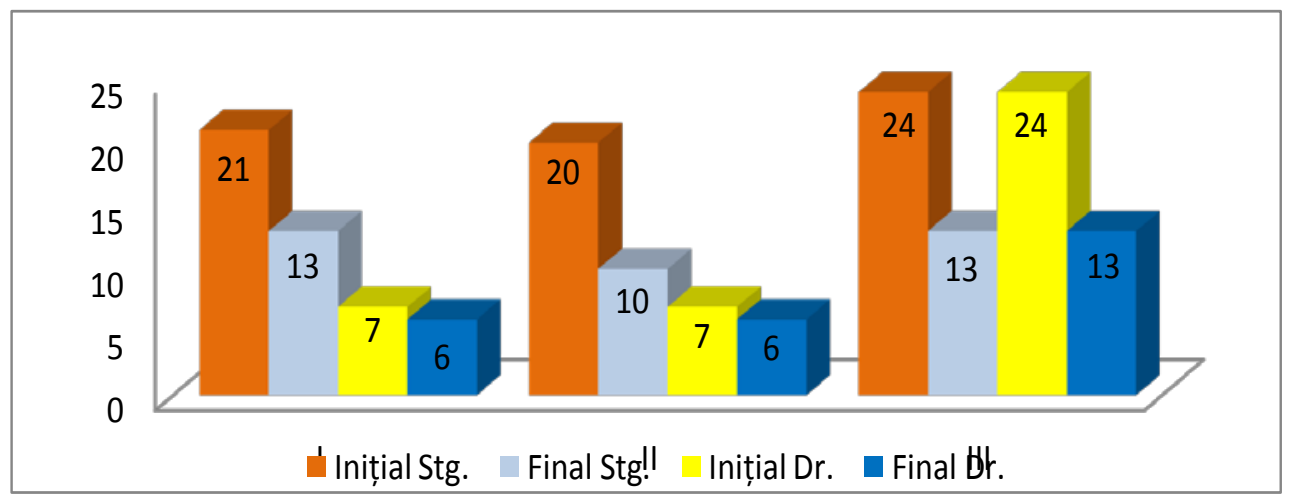

Figura 2. Reprezentarea grafică comparativă a Chestionarului Michigan

Reprezentarea grafică nr. 2, relatează valorile comparative iniţiale și finale obținute la itemii Chestionarului Michigan, privind "funcționalitatea mâinilor în decursul ultimei săptămâni, abilității manuale pentru a îndeplini diverse sarcini pe parcursul ultimei săptămâni, precum și acțiuni ce au vizat funcționalitatea mâinilor simultan".

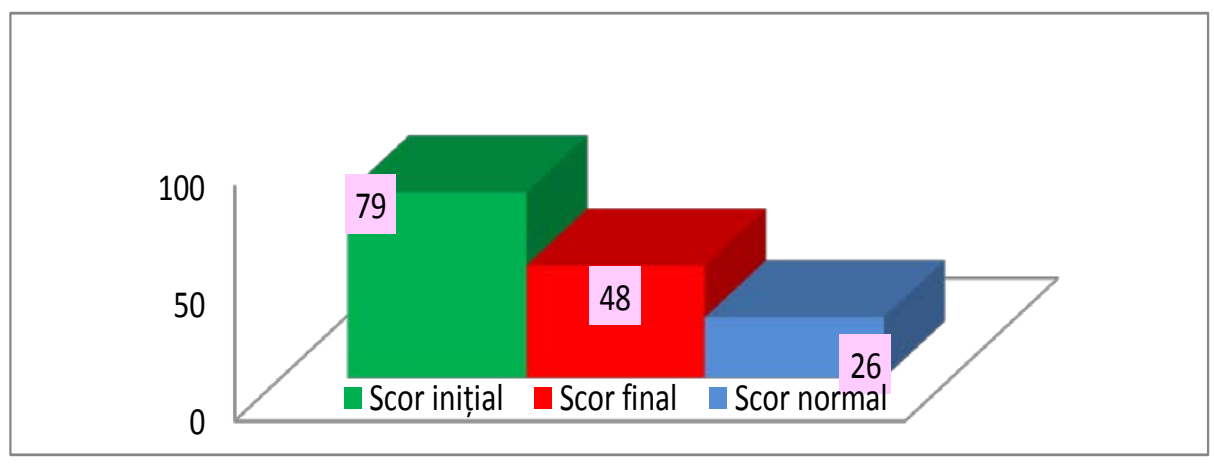

Figura 3. Reprezentarea grafică a Chestionarului Michigan

Graficul nr. 3 prezintă evoluția pozitivă a valorilor inițiale și finale obținute, în raport cu valoarea normală a Chestionarului Michigan. 
În urma aplicării Chestionarului Michigan, pentru nivelul I privind itemii "funcționalității mâinilor în decursul ultimei săptămâni", la evaluarea inițială a membrului superior stâng, s-au obținut 21 puncte, cu o diferență de 16 puncte față de normal (5 puncte), iar pentru membrul superior drept, s-au obținut 7 din 5 puncte, cu o diferență de 2 puncte.

După evaluarea finală, la nivelul membrului superior stâng, s-au obținut 13 puncte din 5 , cu o diferență de 8 puncte, și la nivelul membrului superior drept, sau obținut 6 din 5 puncte.

Pentru nivelul II privind itemii ce vizează "abilitatea mâinilor pentru a îndeplini diverse sarcini pe parcursul ultimei săptămâni", membrul superior stâng a obținut 20 puncte din 5 normal la evaluarea inițială, și 10 din 5 puncte la evaluarea finală, cu o progresivitate descendentă de 10 puncte. Membrul superior drept a obținut inițial 7 puncte, iar final, 6 puncte din 5 normal.

În cadrul nivelului III, privind "acțiunile cu ambele mâini", la evaluarea inițială s-au obținut 24/6 puncte, iar la evaluarea finală 13/6 puncte, cu o progresivitate de 11 puncte. Prezentând valorile obținute detaliat pe fiecare nivel din cadrul chestionarului, se concluzionează că la nivel global, în cazul acestuia, sau obținut per total 79/16 puncte inițial și 48/16 puncte final, cu o diferență de 31 puncte.

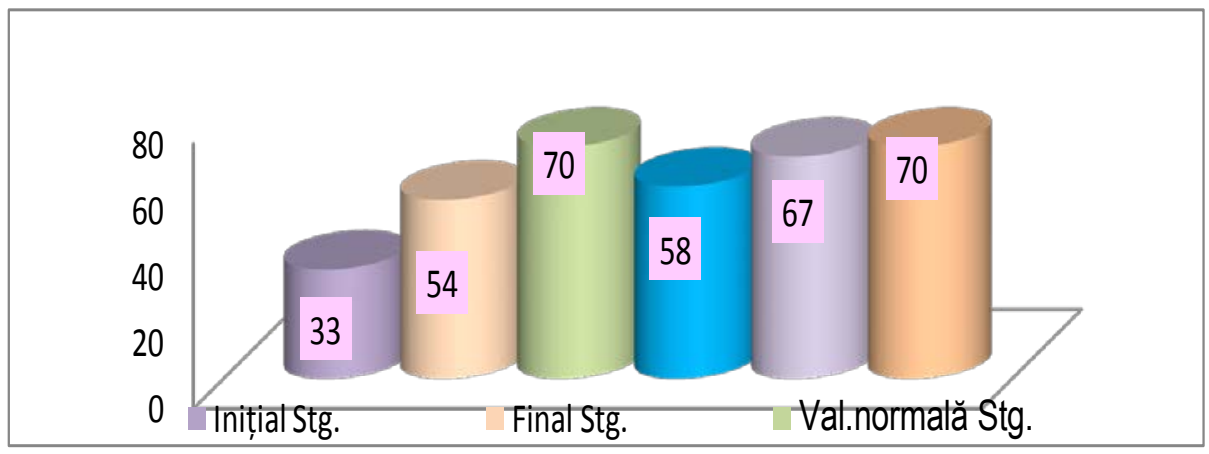

Figura 4. Reprezentarea grafică a evoluției Bilanțului motor global

Reprezentarea grafică nr. 4, evidențiază evoluția crescătoare a valorilor obținute în urma testării inițiale și finale a mișcărilor normale ale mâinii în diverse activități din cadrul Bilanțului Motor Global.

Bilanțul motor global, evidențiază o progresivitate de 21 puncte pentru membrul superior stâng, obținându-se inițial 33 puncte și final 54 puncte/70, și 9 puncte pentru membrul superior drept, astfel s-au obținut 58/70 puncte inițial și $67 / 70$ puncte final. 


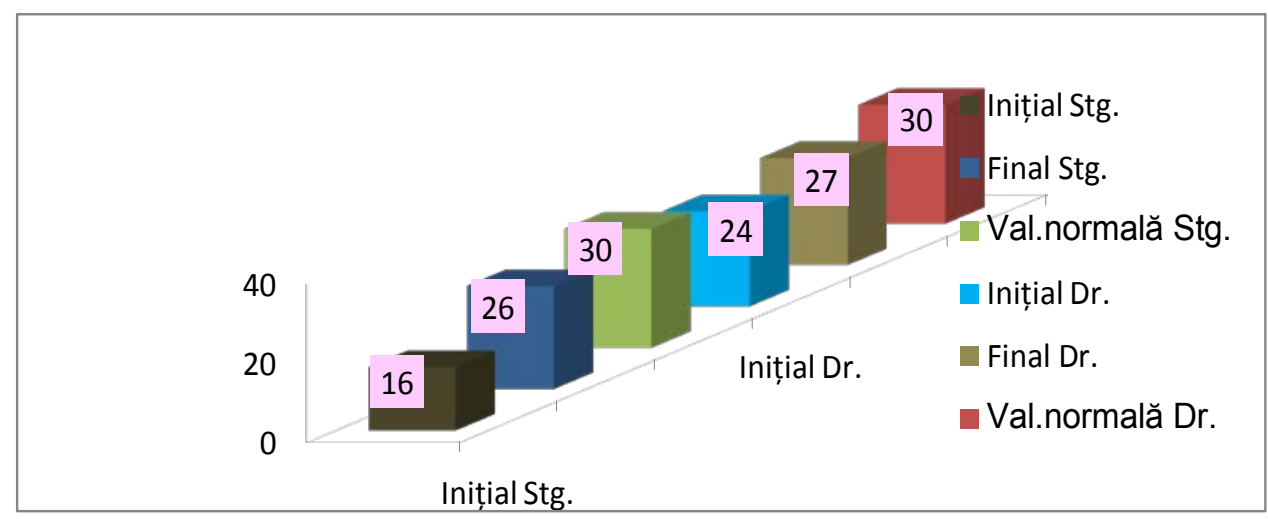

Figura 5. Reprezentarea grafică a Prehensiunii

Graficul nr. 5 prezintă evoluția pozitivă a valorilor inițiale și finale obținute, în raport cu valoarea normală a Prehensiunii.

În cazul tipului de Prehensiune, se evidențiază progresivitatea obținută, astfel inițial sau obținut 16 puncte pentru mâna stângă și final 26 puncte din totalul normal de 30 puncte, mișcările realizându-se parțial sau pe toată amplitudinea, dar cu dificultate. La mâna dreaptă, inițial s-au obținut 24 puncte, iar final 27 puncte, din totalul de 30 puncte.

\section{Discuții}

În această cercetare, am dorit să evidențiez importanţa kinetoterapiei în reeducarea prehensiunii la persoanele de vârsta a III-a, prin evaluarea capacității funcționale, a depistării gradului de dependență funcțională, și prin reeducarea prehensiunii la această categorie de vârstă.

În lucrarea științifică "Mâna dureroasă la pacientul vârstnic" (Nica, Mologhianu, Nartea, Constantinovici, 2015, p. 342), precizează multiplele aspecte fiziopatologice şi clinice ale procesului de îmbătrânire ce se regăsesc la nivelul mâinii.

Acestea, împreună cu durerea, pot determina în grade diferite aspecte disfuncţionale, ce evoluează de la impotenţă funcţională la dizabilitate. Materialul trece în revistă a cele mai frecvente situaţii legate de mâna dureroasă la pacientul vârstnic, mai ales în context reumatismal şi posttraumatic.

Pentru a analiza mâna dureroasă la un pacient vârstnic şi a decide şi selecta oferte personalizate terapeutice şi de recuperare, trebuie trecute în revistă aspectele clinico-funcţionale, sub amprenta multiplelor experienţe patologice şi fiziologice ale vârstnicului, pentru a stabili obiective pertinente şi realiste şi nu de "performanţă". 


\section{Concluzii}

Pe parcursul desfășurării cercetării am avut în vedere realizarea obiectivelor propuse în fiecare etapă și verificarea ipotezelor. Se pot astfel stabili elemente concluzive cu posibilități de generalizare în ceea ce privește importanța kinetoterapiei în reeducarea prehensiunii la persoanele de vârsta a III-a.

Ambele ipoteze se verifică, testele aplicate relevând atât gradul de independență și capacitatea funcțională - inițial, cât și progresul obținut în urma programului de recuperare instituit, astfel "în urma stabilirii nivelului funcțional și prin programele de intervenție specifice, se va îmbunătății capacitatea funcțională a mâinii și implicit creșterea calității vieții".

Comparând rezultatele celor două examinări, inițială și finală, putem constata o îmbunătățire evidentă a prehensiunii pacienților care au fost implicați în cadrul acestei cercetări. Am constatat că nivelul de recuperare al subiecților nu depinde numai de calitatea și cantitatea muncii depuse de kinetoterapeut, ci și de alți factori dintre care amintim: gravitatea leziunii nervoase, aici referindu-ne atât la întinderea leziunii cât și la localizarea ei; potențialul fizic al bolnavului în momentul îmbolnăvirii; precocitatea instituirii tratamentului de recuperare este foarte importantă.

Cu cât se începe mai repede recuperarea, cu atât rezultatele vor fi mai bune. În felul acesta nu vor apărea complicații, cum ar fi retracțiile musculo-tendinoase, pozițiile vicioase. De asemenea, scade riscul de apariție al escarelor și a complicațiilor pulmonare; gradul de participare a bolnavului la propriu tratament.

Participarea pacientului la programul de recuperare trebuie să se facă cu conștiinciozitate, într-o frecvență potrivită cu potențialul fizic al bolnavului și să aibă continuitate.

Dacă, din diverse cauze pacienții nu participă la programul de recuperare, dinamica recuperării este influențată negativ, ducând la o diminuare a ritmului de recuperare. În unele cazuri poate duce chiar la un regres al funcției motorii explicabil prin nestimularea funcției nervoase. 